\title{
UJI INBREEEDING DEPRESSION TERHADAP KARAKTER FENOTIPE TANAMAN JAGUNG MANIS (Zea mays var. Saccharata Sturt) HASIL SELFING DAN OPEN POLLINATED ${ }^{1}$ )
}

\author{
Oleh ; \\ Dwi Rahmawati*), Tommy Yudistira**) dan Saiful Mukhlis***)
}

\begin{abstract}
ABSTRAK
Jagung Manis (Zea mays var. Saccharata Sturt.) merupakan salah satu komoditas hortikultura yang populer di Indonesia. Inbreeding depression adalah fenomena penurunan vigor dan produktivitas tanaman yang disebabkan perkawinan dalam. Inbreeding depression sering diamati pada tanaman jagung yang memiliki karakteristik responsif. Tujuan dari penelitian ini adalah: 1) untuk mengetahui perbedaan karakter fenotip antara tanaman jagung manis (Zea mays saccharata Sturt var) hasil selfing dan hasil open pollinated, 2) untuk mengetahui nilai penurunan vigor tanaman jagung manis (Zea mays var. Saccharata Sturt.) hasil selfing dan open pllinated yang ditandai dengan besaran dan persentase inbreeding depression. Penelitian ini dilakukan pada Agustus-November 2013 di CV. Jogja Horti Lestari Sleman Yogyakarta dengan menggunakan metode percobaan T-test Two Sample Asuming Equals dengan 2 perlakuan. Pada perlakuan open pollinated $(\mathrm{P} 1)$ tanaman diberi perlakuan penyerbukan terbuka hingga mencapai generasi $\mathrm{F} 6$ dan pada perlakuan selfing (P2) tanaman diberi perlakuan penyerbukan sendiri hingga mencapai generasi S5. Hasil penelitian menunjukkan bahwa perlakuan open pollinated (P1) berbeda nyata dengan perlakuan selfing (P2) terhadap semua karakter tanaman kecuali karakter jumlah baris biji per tongkol. Besaran penurunan vigor pada perlakuan selfing (P2) lebih besar dibandingkan dengan perlakuan open pollinated (P1) pada seluruh karakter tanaman yang diamati. Penurunan vigor ditandai dengan besarnya nilai dan persentase Inbreeding depression.
\end{abstract}

Kata Kunci : Inbreeding Depression, Open Pollinated, Selfing, Jagung Manis

\section{PENDAHULUAN}

Jagung manis merupakan salah satu komoditas sayuran paling popular di Amerika Serikat dan Kanada. Konsumsi jagung manis juga mengalami peningkatan di Asia, Eropa dan Amerika Latin serta banyak negara lain, termasuk Indonesia. Konsumsi jagung manis terus mengalami peningkatan seiring dengan pertambahan jumlah penduduk dan pola konsumsi Produksi jagung manis di Indonesia masih belum bisa memenuhi permintaan pasar segar. Hal ini ditunjukkan dengan masih besarnya impor jagung manis segar di Indonesia. Pada tahun 2012 impor jagung manis segar mencapai 2.674 ton (Dirjen Hortikultura, 2012). Oleh karena itu, peluang pengembangan budidaya jagung manis di Indonesia masih sangat besar untuk memenuhi kebutuhan dalam negeri dan mengurangi impor

Penemuan varietas baru merupakan salah satu produk utama hasil penelitian untuk meningkatkan produksi. Varietas jagung hibrida telah terbukti memberikan hasil yang lebih baik dari varietas jagung bersari bebas. Secara umum, varietas hibrida lebih seragam dan mampu berproduksi lebih tinggi 15 - 20\% dari varietas bersari bebas (Morris dalam Suwarno, 2008).

Tahapan pertama program pemuliaan jagung hibrida adalah pembentukan galur-galur murni yang stabil, vigor, serta berdaya hasil benih tinggi. Galur murni dihasilkan dari penyerbukan sendiri hingga diperoleh tanaman yang homozigot. Dengan penyerbukan sendiri, terjadi segregasi dan penurunan vigor tanaman. Selain mengalami penurunan vigor, individu tanaman yang diserbuk sendiri menampakkan berbagai kekurangan seperti: tanaman bertambah pendek, cenderung rebah, peka terhadap penyakit, dan bermacammacam karakter lain yang tidak diinginkan. Munculnya fenomena-fenomena tersebut dikenal dengan istilah depresi tangkar dalam atau inbreeding depression (Poehlman dalam Suwarno, 2008). Pada tanaman jagung yang melakukan penyerbukan terbuka (open pollinated), setiap individu dapat melakukan kawin acak apabila mempunyai kesempatan yang sama untuk membentuk keturunan dan setiap bunga betina dapat diserbuki oleh setiap gamet jantan. Kawin acak yang diikuti seleksi dapat mengubah frekuensi gen, keragaman populasi dan korelasi genetic antara kerabat dekat. Walaupun dapat mengubah frekuensi gen, tetapi kecil pengaruhnya terhadap homozigositas tanaman (Syukur $d k k$., 2012)

Berdasarkan uraian diatas, maka penulis tertarik untuk melakukan penelitian tentang 
pengujian inbreeding depression terhadap tanaman jagung hasil Selfing dan Open Pollinated

\section{BAHAN DAN METODE}

Penelitian ini dilaksanakan bulan Agustus sampai dengan bulan November 2013. Bertempat di CV. Jogja Horti Lestari (JHL) yang terletak di Jalan Kaliurang Km. 11 Kelurahan Sinduharjo Kecamatan Ngaglik Kabupaten Sleman Yogyakarta.

Bahan yang digunakan pada penelitian ini adalah benih jagung generasi $\mathrm{S}_{5}$ dan $\mathrm{F}_{6}$, pupuk Urea, NPK Mutiara, KCl, dan SP36, insektisida dan Fungisida. Alat-alat yang digunakan antara lain cangkul, neraca, gembor, sprayer, alat kocor, meteran dan alat tulis.

Penelitian dilakukan menggunakan metode percobaan T-test Two Sample Asuming Equals terdiri dari dua perlakuan. Perlakuan pertama adalah perlakuan Open Pollinated (P1) dan perlakuan kedua adalah perlakuan Selfing (P2).

Parameter yang diamati dalam penelitian ini antara lain: Tinggi tanaman dan diameter batang, panjang dan lebar daun, umur berbunga jantan dan betina, umur panen, berat tongkol per tanaman, ukuran tongkol, jumlah baris biji per tongkol, kadar gula biji.

Penelitian yang akan dilakukan ini menggunakan T-test Two Sample Assuming Equal Variances yang terdiri dari satu faktor dengan dua taraf perlakuan. Sesudah dilakukan uji T-test, pada setiap parameter pengamatan dihitung prosentase inbriding depression dengan menggunakan rumus

$$
I D \%=\left[\frac{\left(\bar{S}_{0 i}-\bar{S}_{1 i}\right)}{\bar{S}_{0 i}}\right] x 100
$$

$I D \% \quad$ : Persentase Inbriding Depression

$\bar{S}_{0 i} \quad$ : Rerata Hasil Selfing 0 Generasi ke-i

$\bar{S}_{1 i} \quad$ : Rerata Hasil Selfing 1 Generasi ke-i

Penghitungan parameter menggunakan data pengamatan dan data sekunder masing-masing perlakuan hasil penanaman musim sebelumnya. Penghitungan prosentase inbriding depression (ID\%) menggunakan data karakter tanaman induk sumber benih.

\section{HASIL DAN PEMBAHASAN}

\subsection{Tinggi Tanaman dan Diameter Batang}

Hosang et al. dalam Jafri (2006) menyatakan bahwa tinggi tanaman berkaitan erat dengan kerebahan batang, semakin tinggi suatu individu makin besar peluang individu tanaman tersebut mengalami kerebahan. Hal ini akan berpengaruh terhadap produktivitas tanaman terutama bila ditanam pada lokasi yang rentan terhadap kecepatan angin. Hasil T-test Two Sample Assuming Equal Variances parameter tinggi tanaman dan diameter batang disajikan pada Tabel 4.1

Tabel 4.1 Hasil Uji T Pada Taraf 5\% dengan Parameter Tinggi Tanaman dan Diameter Batang (cm)

\begin{tabular}{ccc}
\hline \multirow{2}{*}{ Perlakuan } & \multicolumn{2}{c}{ Rerata } \\
\cline { 2 - 3 } & Tinggi & $\begin{array}{c}\text { Diameter } \\
\text { Tanaman }\end{array}$ \\
Batang \\
\hline P1 (JM001 F6) & $208,85 \mathrm{a}$ & $2,30 \mathrm{a}$ \\
P2 (JM001 S 5$)$ & $168,65 \mathrm{~b}$ & $1,79 \mathrm{~b}$ \\
T 5\% & 1,99 & 1,99 \\
\hline
\end{tabular}

Keterangan: Huruf yang sama menunjukkan berbeda tidak nyata pada uji $\mathrm{T}$ taraf $5 \%$.

Berdasarkan hasil uji $T$ pada Tabel 4.1 di atas diketahui bahwa pada parameter tinggi tanaman perlakuan open pollinated (P1) memiliki rerata tinggi tanaman tertinggi yaitu $208,85 \mathrm{~cm}$ dan berbeda sangat nyata dengan perlakuan selfing (P2) sebesar 168,65 cm. Pada parameter diameter batang perlakuan open pollinated $(\mathrm{P} 1)$ memiliki rerata diameter batang tertinggi yaitu $2,30 \mathrm{~cm}$ dan berbeda nyata dengan perlakuan selfing (P2) sebesar $1,79 \mathrm{~cm}$. Nilai tengah pada kedua parameter, tanaman perlakuan selfing (P2) lebih kecil dibandingkan dengan tanaman open pollinated (P1). Diduga tanaman hasil perlakuan selfing (P2) memiliki homozigositas yang lebih tinggi bila dibandingkan dengan tanaman hasil open pollinated (P2). Homozigositas tanaman lebih cepat tercapai dengan kegiatan selfing.. Homozigositas berkaitan dengan pola pengaruh depresi inbriding yaitu semakin homozygous maka vigor dan produktivitas inbrida makin berkurang (Takdir $d k \mathrm{k} ., 2008$ ).



Gambar 4.1 Perbedaan Tinggi Tanaman Jagung P1 dan P2

Berdasarkan nilai tengah yang didapatkan, persentase inbreeding depression pada parameter tinggi tanaman dan diameter batang dapat dilihat pada Tabel 4.2 
Dwi Rahmawati, Tommy Yudistira,dan Saiful Mukhlis, Uji Inbreeding Depression Terhadap Karakter fenotipe Tanaman Jagung Manis (Zea mays var.Saccharata Sturt) Hasil Selfing Dan Pollinated

Tabel 4.2 Inbreeding Depression Pada Parameter Tinggi Tanaman dan Diameter Batang



Pada Tabel 4.2 dapat diamati bahwa persentase Inbreeding Depression (ID) pada parameter tinggi tanaman, perlakuan selfing (P2) memiliki nilai lebih besar yaitu $21,56 \%$ daripada perlakuan open pollinated (P1) sebesar 2,86\%. Artinya perlakuan selfing (P2) mengalami penurunan nilai karakter sebesar $21,56 \%$ dan perlakuan open pollinated (P1) mengalami penurunan nilai karakter sebesar $2,86 \%$ dari populasi asal yang diakibatkan oleh tangkar dalam. Pada parameter diameter batang juga memberikan nilai yang tidak jauh berbeda. Persentase Inbreeding Depression (ID) pada perlakuan selfing (P2) lebih besar yaitu $22,17 \%$ daripada perlakuan open pollinated (P1) sebesar 0\%. (Jones dalam Moentono, 1983) melakukan penelitian dengan melakukan penyerbukan sendiri untuk tiga inbrida sampai generasi ke-30 dengan hasil setelah 5 generasi penyerbukan sendiri tinggi tanaman turun $30 \%$ dengan sedikit sekali perubahan sesudahnya. Arnhold et al. (2010) juga melakukan penelitian dengan melakukan penyerbukan sendiri terhadap 6 galur popcorn brazil dengan hasil setelah satu generasi rerata tinggi tanaman turun $18 \%$.

\subsection{Panjang Daun dan Lebar Daun}

Laju pertumbuhan nisbi adalah peningkatan bobot kering tanaman dalam suatu interval waktu tertentu saja, bukan pertambahan bobot kering tanaman. Nilai laju pertumbuhan nisbi erat kaitannya dengan efisiensi penyerapan cahaya oleh daun, dalam hal ini luas daun dan laju asimilasi bersih akan mempengaruhi laju pertumbuhan nisbi. Luas daun meningkat dengan diimbangi laju asimilasi bersih yang tinggi, akan menghasilkan laju pertumbuhan nisbi yang tinggi pula (Harjadi, 1991). Hasil T-test Two Sample Assuming Equal Variances parameter panjang daun dan lebar daun disajikan pada Tabel 4.3 di bawah ini:
Tabel 4.3 Hasil Uji T Pada Taraf 5\% dengan Parameter Panjang Daun dan Lebar Daun $(\mathrm{cm})$

\begin{tabular}{ccc}
\hline \multirow{2}{*}{ Perlakuan } & \multicolumn{2}{c}{ Rerata } \\
\cline { 2 - 3 } & Panjang Daun & $\begin{array}{c}\text { Lebar } \\
\text { Daun }\end{array}$ \\
\hline P1 (JM001 F6) & $92,16 \mathrm{a}$ & $9,00 \mathrm{a}$ \\
P2 (JM001 S $)$ & $68,20 \mathrm{~b}$ & $7,46 \mathrm{~b}$ \\
T 5\% & 1,99 & 1,99 \\
\hline
\end{tabular}

Keterangan: Huruf yang sama menunjukkan berbeda tidak nyata pada uji $\mathrm{T}$ taraf $5 \%$.

Berdasarkan hasil T-test Two Sample Assuming Equal Variances pada Tabel 4.5 di atas diketahui bahwa pada parameter panjang daun, perlakuan open pollinated (P1) memiliki rerata panjang daun tertinggi yaitu $2,30 \mathrm{~cm}$ dan berbeda nyata dengan perlakuan selfing (P2) sebesar 1,79 $\mathrm{cm}$. Pada parameter lebar daun diketahui bahwa perlakuan open pollinated $(\mathrm{P} 1)$ memiliki rerata lebar daun tertinggi yaitu $9,00 \mathrm{~cm}$ dan berbeda nyata dengan perlakuan selfing (P2) sebesar 7,46 $\mathrm{cm}$. Berkaitan dengan efek tangkar dalam, perbedaan ini diduga karena tanaman jagung hasil selfing (P2) mengalami penurunan karakterkarakter tanaman. Berbeda dengan tanaman hasil selfing, tanaman hasil open pollinated (P1) cenderung memiliki keunggulan karakter kuantitatif yang berkembang karena banyaknya gen pendukung. Menurut Syukur $d k k$. (2012), gengen pendukung pada tanaman menyerbuk silang akan menunjukkan keunggulan masing-masing dari gen pengendalinya dan berpengaruh pada pertumbuhan yang lebih baik. Oleh karena itu perlakuan open pollinated (P1) memiliki rerata panjang daun dan lebar daun yang lebih besar dibandingkan dengan perlakuan selfing (P2).

Berdasarkan nilai tengah yang didapatkan, persentase inbreeding depression pada parameter panjang daun dan lebar daun dapat dilihat pada Tabel 4.4 di bawah ini:

Tabel 4.4 Inbreeding Depression Pada Parameter Panjang Daun dan Lebar Daun (cm)

\begin{tabular}{cccc}
\hline \multirow{2}{*}{ Galur } & Generasi & \multicolumn{2}{c}{ Estimasi Parameter } \\
\cline { 3 - 4 } & & Panjang & $\begin{array}{c}\text { Lebar } \\
\text { Daun }\end{array}$ \\
\hline P1 & ID & 0,34 & 0,26 \\
$(J M 001$ & ID\% & 0,36 & 2,76 \\
F $\left._{6}\right)$ & ID & 24,30 & 1,81 \\
P2 & ID\% & 26,27 & 19,51 \\
$\left(\mathrm{JM}^{2} 001\right.$ &
\end{tabular}

Keterangan : ID = Inbreeding Depression 


$$
\% \text { ID }=\underset{\text { Inbreeding Depression }}{\text { dalam persentase }}
$$

Pada Tabel 4.4 dapat diamati bahwa karakter panjang daun tanaman perlakuan open pollinated (P1) memiliki presentase inbriding depression yang sangat kecil yaitu $0,36 \%$ bila dibandingkan dengan tanaman perlakuan selfing (P2) dengan persentase inbriding depression 26,27\%. Syukur $d k k$. (2012) menyatakan bahwa dalam kaitannya dengan seleksi tanaman menyerbuk silang, walaupun intensitas seleksi dapat meningkatkan kemajuan, tetapi pada tingkat terlalu tinggi dapat menghasilkan tanamantanaman mempunyai kesamaan genotipe sehingga meningkatkan jumlah gen homozigot pada keturunannya. Dengan demikian, dapat menyebabkan tangkar dalam. Hasil penelitian menunjukkan bahwa tanaman jagung manis yang diperlakukan menggunakan metode selfing memperlihatkan fenomena depresi tangkar dalam.

Pada Tabel 4.4 juga dapat diamati bahwa presentase Inbreeding Depression (ID) untuk lebar daun pada perlakuan selfing (P2) lebih besar yaitu $19,51 \%$ daripada perlakuan open pollinated (P1) sebesar 2,76\%. Takdir $d k k$. (2008) menyatakan bahwa tanaman hasil open pollinated lebih lama mencapai homozigot karena sifat tanaman jagung yang menyerbuk silang sehingga kemungkinan untuk silang diri (inbriding) sangat kecil $(<1 \%)$. Sehingga tanaman dengan perlakuan open pollinated ( $\mathrm{P} 1)$ tidak banyak mengalami perubahan morfologi karena tanaman menyerbuk secara bebas dan kemungkinan silang diri penyebab depresi inbriding prosentasenya sangat kecil.

\subsection{Umur Berbunga Jantan dan Betina}

Umur berbunga merupakan salah satu karakter yang sangat penting. Umur berbunga yang cepat (genjah) adalah karakter yang diinginkan, dikarenakan umur berbunga berhubungan dengan umur panen dimana semakin cepat umur berbunga maka waktu panen juga akan semakin cepat. Umur berbunga juga digunakan untuk menentukan jarak waktu tanam benih induk jantan dan betina pada kegiatan produksi benih. Hasil T-test Two Sample Assuming Equal Variances parameter umur berbunga jantan (day to anthesis) dan umur berbunga betina (day to silking) disajikan pada Tabel 4.5 di bawah ini:

Tabel 4.5 Hasil Uji T Pada Taraf 5\% dengan Parameter Umur Berbunga Jantan (Days To Antesis) dan Umur
Berbunga Betina (Days To Silking) (HST)

\begin{tabular}{ccc}
\hline \multirow{2}{*}{ Perlakuan } & \multicolumn{2}{c}{ Rerata } \\
\cline { 2 - 3 } & DTA & DTS \\
\hline P1 (JM001 F6) & $50,40 \mathrm{a}$ & $51,35 \mathrm{a}$ \\
P2 (JM001 S5) & $54,75 \mathrm{~b}$ & $54,96 \mathrm{~b}$ \\
T 5\% & 1,99 & 1,99 \\
\hline
\end{tabular}

Keterangan: Huruf yang sama menunjukkan berbeda tidak nyata pada uji $\mathrm{T}$ taraf $5 \%$.

$$
\begin{aligned}
& \text { DTA }=\text { Days to Anthesis } \\
& \text { DTS }=\text { Days to Silking }
\end{aligned}
$$

Berdasarkan hasil uji T-test Two Sample Assuming Equal Variances pada Tabel 4.9 di atas diketahui bahwa pada parameter umur berbunga jantan (anthesis) perlakuan selfing (P2) memiliki rerata umur berbunga jantan tertinggi yaitu 54,75 HST dan berbeda nyata dengan perlakuan open pollinated (P1) sebesar 50,40 cm. Sedangkan pada parameter umur berbunga betina (silking) selfing (P2) memiliki rerata umur berbunga betina tertinggi yaitu 54,96 HST dan berbeda nyata dengan perlakuan open pollinated (P1) sebesar $51,35 \mathrm{~cm}$

Berdasarkan rerata nilai tengah yang didapatkan, persentase inbreeding depression pada parameter umur berbunga jantan dapat dilihat pada Tabel 4.6 di bawah ini:

Tabel 4.6 Inbreeding Depression Pada Parameter Parameter Umur Berbunga Jantan (Days To Antesis) dan Umur Berbunga Betina (Days To Silking) (HST)

\begin{tabular}{cccc}
\hline \multirow{2}{*}{ Galur } & \multirow{2}{*}{ Generasi } & \multicolumn{2}{c}{ Estimasi Parameter } \\
\cline { 3 - 4 } & & DTA & DTS \\
\hline P1 (JM001 & ID & 0,10 & 1,15 \\
$\left.\mathrm{~F}_{6}\right)$ & ID\% & 0,20 & 2,19 \\
P2 (JM001 & ID & $-4,25$ & $-2,48$ \\
$\left.\mathrm{~S}_{5}\right)$ & ID\% & $-8,46$ & $-4,72$ \\
\hline Keterangan : DTA $=$ Days to Anthesis \\
& DTS $=$ Days to Silking \\
& ID $=$ Inbreeding Depression \\
& $\%$ ID $=$ Inbreeding Depression
\end{tabular}

Jafri (2006) menyatakan bahwa perbedaan antara umur masak pollen dan umur keluar rambut tongkol (silkdelay) berpengaruh terhadap pengisian biji tongkol. Semakin dekat jaraknya semakin baik untuk proses penyerbukan rambut tongkol oleh serbuk sari. Sebaliknya, semakin jauh jaraknya semakin berkurang serbuk sari yang menyerbuki rambut tongkol. Sinkronisasi antara masaknya polen dan umur keluar rambut 
Dwi Rahmawati, Tommy Yudistira,dan Saiful Mukhlis, Uji Inbreeding Depression Terhadap Karakter fenotipe Tanaman Jagung Manis (Zea mays var.Saccharata Sturt) Hasil Selfing Dan Pollinated

berpengaruh terhadap hasil biji, semakin besar "silkdelay" semakin berkurang hasil (Islam dan Kaul dalam Jafri, 2006). Moentono dalam Jafri (2006) juga menjelaskan, perbedaan yang umum biasanya berkisar antara 3-4 hari atau sedikit lebih lama. Pada Tabel 4.6 dapat diamati bahwa persentase Inbreeding Depression (ID) untuk umur berbunga jantan (anthesis) pada perlakuan open pollinated $(\mathrm{P} 1)$ lebih besar yaitu $0,20 \%$ daripada perlakuan selfing (P2) sebesar $-8,46 \%$. Presentase depresi inbriding pada perlakuan selfing (P2) menunjukkan nilai minus, artinya tanaman jagung manis perlakuan selfing (P2) memiliki umur berbunga jantan lebih dalam dibandingkan populasi asal $\left(\mathrm{S}_{0}\right)$. Diduga hal ini berkaitan dengan efek inbriding depression yang menyebabkan melemahnya karakter-karakter tanaman termasuk umur berbunga jantan. Allard dalam Siradjuddin (2000) menyatakan bahwa inbreeding pada jagung menyebabkan vigor dan produktivitas rendah serta waktu pembungaan menjadi lebih lambat .

Persentase Inbreeding Depression (ID) untuk umur berbunga betina (silking) pada perlakuan open pollinated $(\mathrm{P} 1)$ lebih besar yaitu 2,19\% daripada perlakuan selfing (P2) sebesar $4,72 \%$. Presentase depresi inbriding pada perlakuan open pollinated (P1) menunjukkan nilai plus, artinya tanaman jagung manis perlakuan open pollinated ( $\mathrm{P} 1)$ memiliki umur berbunga jantan lebih genjah dibandingkan populasi asal $\left(\mathrm{S}_{0}\right)$. Diduga hal ini berkaitan dengan kemajuan seleksi yang dapat merubah frekuensi gen yakni kearah frekuensi gen yang dikehendaki. Seleksi pada tahap $\mathrm{F}_{1}-\mathrm{F}_{6}$ nantinya diarahkan untuk memperbesar gen yang diinginkan (Syukur $d k k$., 2012). Salah satu tujuan seleksi yaitu untuk mendapatkan tanaman yang memiliki umur berbunga lebih genjah daripada populasi asal.

\subsection{Umur Panen}

Umur panen merupakan salah satu karakter yang digunakan untuk mengukur keunggulan suatu varietas. Varietas jagung manis yang diinginkan adalah varietas yang memiliki umur panen lebih awal (genjah). Umur tanaman berkaitan dengan lamanya tanaman di lapangan. Semakin singkat tanaman berada di lapangan akan semakin baik, karena dapat mengurangi intensitas serangan hama dan penyakit (Syukur dan Rifianto, 2013). Hasil uji T-test Two Sample Assuming Equal Variances parameter umur panen disajikan pada Tabel $4.7 \mathrm{di}$ bawah ini:

Tabel 4.7 Hasil Uji T Pada Taraf 5\% dengan Parameter Umur Panen (HST)

\begin{tabular}{cc}
\hline Perlakuan & Rerata \\
\hline P1 (JM001 $\left.\mathrm{F}_{6}\right)$ & $69,90 \mathrm{a}$ \\
P2 $\left(\mathrm{JM}_{5}\right.$ 001 S & $73,40 \mathrm{~b}$ \\
T 5\% & 1,99 \\
\hline
\end{tabular}

Keterangan: Huruf yang sama menunjukkan berbeda tidak nyata pada uji $\mathrm{T}$ taraf $5 \%$.

Berdasarkan hasil T-test Two Sample Assuming Equal Variances pada Tabel 4.7 di atas diketahui bahwa perlakuan selfing (P2) memiliki rerata umur panen tertinggi yaitu 73,40 HST dan berbeda nyata dengan perlakuan open pollinated (P1) sebesar 69,90 cm.

Berdasarkan uji nilai tengah yang didapatkan, persentase inbreeding depression pada parameter umur panen dapat dilihat pada Tabel 4.8 di bawah ini

Tabel 4.8 Inbreeding Depression Pada Parameter Umur Panen (HST)

\begin{tabular}{ccc}
\hline Galur & $\begin{array}{c}\text { Diameter } \\
\text { Batang }\end{array}$ & Estimasi \\
\hline \multirow{2}{*}{ P1 (JM001 F6) } & ID & 2,60 \\
& ID $\%$ & 3,59 \\
P2 (JM001 S5) & ID & $-0,9$ \\
& ID $\%$ & $-1,24$ \\
\hline Keterangan : ID & $\begin{array}{l}=\text { Inbreeding Depression } \\
\text { \%ID } \\
\end{array}$ & Inbreeding Depression \\
dalam persentase
\end{tabular}

Pada Tabel 4.8 dapat diamati bahwa persentase Inbreeding Depression (ID) untuk umur panen pada perlakuan open pollinated (P1) lebih besar yaitu 3,59\% daripada perlakuan selfing (P2) sebesar $-1,24 \%$. Presentase depresi inbriding pada perlakuan open pollinated (P1) menunjukkan nilai plus, artinya tanaman jagung manis perlakuan open pollinated $(\mathrm{P} 1)$ memiliki umur panen lebih cepat (genjah) dibandingkan populasi asal $\left(\mathrm{F}_{1}\right)$. Sebaliknya presentase depresi inbriding pada perlakuan selfing (P2) menunjukkan nilai minus, artinya tanaman jagung manis perlakuan selfing (P2) memiliki umur panen lebih dalam dibandingkan populasi asal $\left(\mathrm{S}_{0}\right)$. Umur panen yang lebih dalam pada perlakuan selfing (P2) menunjukkan adanya penurunan karakter yang diakibatkan oleh inbriding. Pada tanaman jagung manis umur berbunga mempengaruhi umur panen tongkol segar. Berdasarkan data umur berbunga pada Tabel 4.5, perlakuan open pollinated (P1) memliki umur berbunga yang lebih cepat dibandingkan dengan perlakuan selfing (P2), maka umur panen tanaman perlakuan open pollinated 
(P1) pun lebih genjah daripada perlakuan selfing (P2).

\subsection{Berat Tongkol Per Tanaman}

Berat tongkol per tanaman meupakan karakteristik keunggulan yang sangat penting pada jagung manis karena berkaitan langsung dengan produktifitas suatu varietas.. Hasil T-test Two Sample Assuming Equal Variances parameter berat tongkol per tanaman disajikan pada tabel 4.9 di bawah ini:

Tabel 4.9 Hasil Uji T Pada Taraf 5\% Dengan Parameter Berat Tongkol Per Tanaman (gr)

\begin{tabular}{cc}
\hline Perlakuan & Rerata \\
\hline P1 $\left(\mathrm{JM} 001 \mathrm{~F}_{6}\right)$ & $214,11 \mathrm{a}$ \\
P2 $\left(\mathrm{JM} 001 \mathrm{~S}_{5}\right)$ & $115,79 \mathrm{~b}$ \\
T 5\% & 1,99 \\
\hline
\end{tabular}

Keterangan: Huruf yang sama menunjukkan berbeda tidak nyata pada uji $\mathrm{T}$ taraf $5 \%$.

Berdasarkan uji nilai tengah yang didapatkan, persentase Inbreeding Depression pada berat tongkol per tanaman dapat dilihat pada Tabel 4.10

Tabel 4.10 Inbreeding Depression Pada Parameter Berat Tongkol Per Tanaman (gr)

\begin{tabular}{ccc}
\hline Galur & Generasi & $\begin{array}{c}\text { Estimasi Berat } \\
\text { Tongkol Per } \\
\text { Tanaman (gr) }\end{array}$ \\
\hline P1 (JM001 F6) & ID & 210,89 \\
& ID\% & 49,62 \\
P2 (JM001 S 5$)$ & ID & 309,213 \\
& ID\% & 72,76 \\
\hline Keterangan : ID & $=$ Inbreeding Depression \\
\%ID & $=$ Inbreeding Depression \\
& dalam persentase
\end{tabular}

Berdasarkan hasil uji $T$ pada Tabel 4.9 di atas diketahui bahwa pada parameter panjang tongkol perlakuan open pollinated $(\mathrm{P} 1)$ memiliki rerata tertinggi yaitu 214,11 gr dan berbeda nyata dengan perlakuan selfing (P2) sebesar 115,79 gr.

Pada tabel 4.10 dapat diamati bahwa persentase Inbreeding Depression (ID) pada parameter berat tongkol per tanaman perlakuan selfing (P2) memiliki nilai lebih besar yaitu $72,76 \%$ daripada perlakuan open pollinated $(\mathrm{P} 1)$ sebesar $49,62 \%$. Penurunan nilai berat tongkol per tanaman yang tinggi pada tanaman perlakuan selfing (P2) diduga akibat perlakuan inbriding terus menerus sehingga memperlemah karakter tanaman. Berat tongkol per tanaman memiliki nilai inbreeding depression tertinggi dibandingkan dengan karakter lain. Saleh et al. (1993) melakukan penelitian pada dua galur inbred, setelah satu generasi terjadi penurunan sebesar $36,47 \%$ pada karakter berat tongkol. Karakter tongkol memiliki tingkat inbreeding tertinggi karena dikendalikan oleh gen dengan jumlah lebih besar (Genter dalam Saleh et al., 1993). Saleh et al. (1993) juga menyatakan bahwa tingkat inbreeding yang tinggi pada karakter hasil juga dilaporkan oleh Genter (1971); Harris et al. (1972); Marsum (1972); Hallauer dan Sears (1973); Cornelius dan Dudley (1974).

Mugnisjah $d k k$. (1994) menyatakan bahwa memproduksi jagung hybrid, apalagi hibrida silang tunggal menghadapi kendala lain antara lain pada lemahnya vigor tetua jantan dan betina akibat adanya inbriding depression pada tetua-tetua ini.; hal ini acapkali terlihat pada sedikitnya tepung sari yang dihasilkan tetua jantan, serta kecilnya tongkol-tongkol tetua jagung ini. Sedikitnya tepung sari dapat mengurangi hasil tanaman karena serbuk sari yang sedikit dapat mengakibatkan tongkol tidak terisi biji sempurna

Gardner et al. dalam Cepy dan Wangiyana (2011) menyatakan bahwa tinggi rendahnya pertumbuhan serta hasil tanaman dipengaruhi oleh dua faktor yaitu faktor internal dan faktor eksternal. Faktor internal merupakan faktor yang dipengaruhi oleh sifat genetik atau sifat turunan seperti usia tanaman, morfologi tanaman, daya hasil, kapasitas menyimpan cadangan makanan, ketahanan terhadap penyakit dan lain-lain. Faktor eksternal merupakan faktor lingkungan, seperti iklim, tanah dan faktor biotik. Perbedaan pertumbuhan dan hasil yang diperoleh diduga disebabkan oleh satu atau lebih dari faktor tersebut.

Selain faktor inbreeding penurunan nilai berat tongkol per tanaman yang tinggi baik pada perlakuan open pollinated ( $\mathrm{P} 1)$ maupun selfing (P2) diduga disebabkan oleh lingkungan tumbuh yang kurang mendukung. Menurut Harjadi dalam Made (2010), pertumbuhan dan mutu hasil jagung manis diduga dipengaruhi oleh faktor lingkungan kesuburan tanah. Bedengan yang digunakan dalam penelitian ini sering digunakan untuk kegiatan produksi sehingga struktur tanahnya telah padat. Tanah yang memiliki struktur padat membatasi penetrasi akar dalam mendapatkan hara dan air ataupun udara untuk pertumbuhannya (Morachan et al. dalam Lumbanraja, 2013)

Keadaan tanah yang sangat keras dan padat menyebabkan akar sulit menembus agregat tanah 
Dwi Rahmawati, Tommy Yudistira,dan Saiful Mukhlis, Uji Inbreeding Depression Terhadap Karakter fenotipe Tanaman Jagung Manis (Zea mays var.Saccharata Sturt) Hasil Selfing Dan Pollinated

dan membatasi daya eksplorasi akar, bahkan bisa saja akar mengalami kerusakan. Jika daya eksplorasi akar terhambat, maka akan mengurangi total luas permukaan akar yang dapat berhubungan langsung dengan tanah. Padahal menurut Gardner et al. dalam Cepy dan Wangiyana (2011), akar merupakan organ vegetatif utama yang memasok air, unsur hara serta bahan-bahan lain yang dibutuhkan untuk pertumbuhan dan perkembangan tanaman. Jika akar tidak berkembang dengan baik maka kemampuan akar dalam menyerap air dan unsur hara akan menurun, sehingga menyebabkan tanaman tidak akan mendapat air dan unsur hara secara optimal. Perbedaan ukuran tongkol pada perlakuan $O P(\mathrm{P} 1)$ dan selfing $(\mathrm{P} 2)$ dapat dilihat pada Gambar 4.2

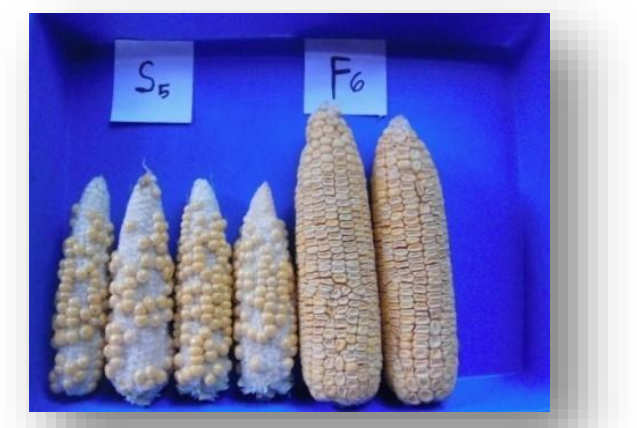

Gambar 4.2 Perbedaan Ukuran Tongkol P1 dan P2

\subsection{Panjang Tongkol dan Diameter Tongkol}

Selain produktivitas, ukuran tongkol merupakan salah satu karakter penting pada jagung manis. Konsumen menginginkan jagung manis yang memiliki ukuran tongkol yang relative besar, biji terisi penuh, dan diameter ujung tidak berbeda jauh dengan diameter pangkal tongkol. Hasil T-test Two Sample Assuming Equal Variances parameter panjang tongkol dan diameter tongkol disajikan pada Tabel 4.11 di bawah ini:

Tabel 4.11 Hasil Uji T Pada Taraf 5\% Dengan Parameter Panjang Tongkol dan Diameter Tongkol (cm)

\begin{tabular}{ccc}
\hline \multirow{2}{*}{ Perlakuan } & Rerata & \\
\cline { 2 - 3 } & $\begin{array}{c}\text { Panjang } \\
\text { Tongkol }\end{array}$ & $\begin{array}{c}\text { Diameter } \\
\text { Tongkol }\end{array}$ \\
\hline P1 (JM001 F6) & $18,42 \mathrm{a}$ & $4,61 \mathrm{a}$ \\
P2 $($ JM001 S 5$)$ & $14,76 \mathrm{~b}$ & $3,97 \mathrm{~b}$ \\
T 5\% & 1,99 & 1,99 \\
\hline
\end{tabular}

Keterangan: Huruf yang sama menunjukkan berbeda tidak nyata pada uji $\mathrm{T}$ taraf $5 \%$.
Berdasarkan hasil uji $T$ pada Tabel 4.9 di atas diketahui bahwa pada parameter panjang tongkol perlakuan open pollinated (P1) memiliki rerata tertinggi yaitu $18,42 \mathrm{~cm}$ dan berbeda nyata dengan perlakuan selfing (P2) sebesar 14,76 cm. Pada parameter diameter tongkol perlakuan open pollinated (P1) memiliki nilai tertinggi yaitu 4,61 $\mathrm{cm}$ dan berbeda nyata dengan perlakuan selfing (P2) sebesar 3,97 cm.

Berdasarkan uji nilai tengah yang didapatkan, persentase inbreeding depression pada parameter panjang tongkol dan diameter tongkol dapat dilihat pada Tabel 4.12

Tabel 4.12 Inbreeding Depression Pada Parameter Panjang Tongkol dan Diameter Tongkol (cm)

\begin{tabular}{cccc}
\hline & & \multicolumn{2}{c}{ Estimasi Parameter } \\
\cline { 3 - 4 } Galur & Generasi & $\begin{array}{c}\text { Panjang } \\
\text { Tongkol }\end{array}$ & $\begin{array}{c}\text { Diameter } \\
\text { Tongkol }\end{array}$ \\
\hline P1 (JM001 & ID & 1,08 & 0,54 \\
$\left.\mathrm{~F}_{6}\right)$ & ID\% & 5,55 & 10,51 \\
P2 (JM001 & ID & 4,74 & 1,18 \\
$\left.\mathrm{~S}_{5}\right)$ & ID $\%$ & 24,30 & 22,99 \\
\hline Keterangan : ID & $=$ Inbreeding Depression \\
& $\%$ ID & $=$ Inbreeding Depression & Dalam persentase
\end{tabular}

Pada Tabel 4.10 dapat diamati bahwa persentase Inbreeding Depression (ID) pada parameter panjang tongkol, perlakuan selfing (P2) memiliki nilai lebih besar yaitu $24,30 \%$ daripada perlakuan open pollinated (P1) sebesar 5,55\%. Pada parameter diameter tongkol juga memberikan nilai yang tidak jauh berbeda. Persentase Inbreeding Depression (ID) pada perlakuan selfing (P2) lebih besar yaitu 22,99\% daripada perlakuan open pollinated (P1) sebesar 10,51\%. Efek tangkar dalam terlihat pada karakter panjang tongkol dan diameter tongkol dimana nilai persentase inbreeding depression pada perlakuan selfing (P2) lebih tinggi daripada perlakuan open pollinated (P1). Diduga karakter tanaman perlakuan open pollinated (P1) tidak banyak mengalami penurunan karena perlakuan kawin acak. Syukur $d k k$. (2012) menyatakan bahwa kawin acak yang diikuti seleksi dapat mengubah frekuensi gen, keragaman populasi, dan korelasi genetik antara kerabat dekat. Walaupun dapat mengubah frekuensi gen, kecil kemungkinan pengaruhnya terhadap homozigositas tanaman.

\subsection{Baris Biji Per Tongkol}


Hasil T-test Two Sample Assuming Equal Variances parameter jumlah baris bij per tongkol pada Tabel 4.13 di bawah ini

Tabel 4.13 Hasil Uji T Pada Taraf 5\% Dengan Parameter Jumlah Baris Biji Per Tongkol (no.)

\begin{tabular}{cc}
\hline Perlakuan & Rerata \\
\hline P1 $\left(\mathrm{JM}^{\mathrm{J}} 001 \mathrm{~F}_{6}\right)$ & $15,75 \mathrm{a}$ \\
P2 $\left(\mathrm{JM} 001 \mathrm{~S}_{5}\right)$ & $15,66 \mathrm{a}$ \\
T 5\% & 1,99 \\
\hline
\end{tabular}

Keterangan: Huruf yang sama menunjukkan berbeda tidak nyata pada uji $\mathrm{T}$ taraf $5 \%$.

Berdasarkan hasil uji $T$ pada Tabel 4.9 di atas diketahui bahwa pada parameter jumlah baris bij per tongkol perlakuan open pollinated (P1) memiliki rerata tertinggi yaitu 15,75 dan tidak berbeda nyata dengan perlakuan selfing (P2) sebesar 15,66.

Berdasarkan uji nilai tengah yang didapatkan, persentase inbreeding depression pada jumlah baris bij per tongkol dapat dilihat pada Tabel 4.14

Tabel 4.14 Inbreeding Depression Pada Parameter Jumlah Baris Bij Per Tongkol (no.)

\begin{tabular}{|c|c|c|}
\hline Galur & Generasi & $\begin{array}{c}\text { Estimasi } \\
\text { jumlah baris } \\
\text { biji per } \\
\text { tanaman (no.) }\end{array}$ \\
\hline \multirow{2}{*}{ P1 (JM001 F6) } & ID & 1,25 \\
\hline & ID $\%$ & 7,35 \\
\hline \multirow{2}{*}{ P2 (JM001 S5) } & ID & 1,34 \\
\hline & ID\% & 7,88 \\
\hline Keterangan : ID & \multicolumn{2}{|c|}{$=$ Inbreeding Depression } \\
\hline tento & $=\begin{array}{r}\text { Inbreec } \\
\text { dalam per }\end{array}$ & $\begin{array}{l}\text { ng Depression } \\
\text { ntase }\end{array}$ \\
\hline
\end{tabular}

Pada Tabel 4.14 dapat diamati bahwa pada parameter jumlah baris bij per tongkol, persentase Inbreeding Depression (ID) pada kedua perlakuan tidak jauh berbeda. Perlakuan selfing (P2) memiliki nilai lebih besar yaitu $7,88 \%$ daripada perlakuan open pollinated (P1) sebesar 7,35\%. Diduga tanaman perlakuan selfing (P2) mengalami segregasi lambat sehingga penurunan nilai karakter akan terus berlangsung pada generasi-generasi berikutnya. Hal itu dibuktikan dengan nilai persentase inbreeding depression yang hampir sama dengan perlakuan open pollinated (P2). Hallauer dan Miranda dalam Takdir, dkk. (2008) menyatakan bahwa pada galur murni adakalanya terjadi segregasi lambat, sehingga karakter yang ditentukan oleh gen resesif baru nampak pada generasi lanjut. Hal ini terlihat pada penurunan hasil biji dengan silang diri yang masih terus berlangsung, walaupun sudah mencapai generasi lanjut. Pada generasi 6-10, penurunan hasil 53\% dan pada generasi 25-30 mencapai 79\% .

\subsection{Kadar Kemanisan Biji}

Kadar kemanisan biji merupakan salah satu karakter yang paling utama dalam jagung manis. Jagung manis banyak disukai masyarakat karena memiliki rasa yang manis, rasa manis pada biji jagung manis disebabkan oleh tingginya kadar gula pada endosperm biji jagung manis yang berkisar 13-14\% sedangkan kadar gula jagung biasa hanya 2-3\% (Palungkun dan Budiarti, 1991). Hasil T-test Two Sample Assuming Equal Variances parameter kadar kemanisan biji pada Tabel 4.15 di bawah ini:

Tabel 4.15 Hasil Uji T Pada Taraf 5\% Dengan Parameter Kadar Gula Biji ( ${ }^{\circ}$ brix)

\begin{tabular}{|c|c|}
\hline Perlakuan & Rerata \\
\hline $\mathrm{P} 1\left(\mathrm{JM} 001 \mathrm{~F}_{6}\right)$ & $15,50 \mathrm{a}$ \\
\hline $\mathrm{P} 2\left(\mathrm{JM} 001 \mathrm{~S}_{5}\right)$ & $15,30 \mathrm{~b}$ \\
\hline T $5 \%$ & 1,99 \\
\hline
\end{tabular}

Keterangan: Huruf yang sama menunjukkan berbeda tidak nyata pada uji $\mathrm{T}$ taraf $5 \%$.

Berdasarkan hasil uji $T$ pada Tabel 4.9 di atas diketahui bahwa pada parameter kadar gula biji per tongkol perlakuan open pollinated (P1) memiliki rerata tertinggi yaitu 15,50 dan berbeda nyata dengan perlakuan selfing (P2) sebesar 15,30.

Berdasarkan uji nilai tengah yang didapatkan, persentase inbreeding depression pada karakter kadar gula biji dapat dilihat pada Tabel 4.16

Tabel 4.16 Inbreeding Depression Pada Parameter Kadar Gula Biji ( ${ }^{\circ}$ brix)

\begin{tabular}{ccc}
\hline Galur & Generasi & $\begin{array}{c}\text { Estimasi Kadar } \\
\text { Gula Biji ( }{ }^{\text {brix })}\end{array}$ \\
\hline P1 (JM001 F6) & ID & 0 \\
& ID\% & 0 \\
P2 (JM001 S5) & ID & 0,2 \\
\hline Keterangan : ID & ID $\%$ & 1,29 \\
\%ID & $=$ Inbreeding Depression \\
& \multicolumn{2}{c}{ Inbreeding Depression } \\
\end{tabular}

Pada Tabel 4.16 dapat diamati bahwa pada kadar gula biji, persentase Inbreeding Depression 
Dwi Rahmawati, Tommy Yudistira,dan Saiful Mukhlis, Uji Inbreeding Depression Terhadap Karakter fenotipe Tanaman Jagung Manis (Zea mays var.Saccharata Sturt) Hasil Selfing Dan Pollinated

(ID) pada kedua perlakuan tidak jauh berbeda. Perlakuan selfing (P2) memiliki nilai lebih besar yaitu $1,29 \%$ daripada perlakuan open pollinated (P1) sebesar 0\%. Takdir $d k k .$, (2008) menyatakan bahwa tanaman hasil open pollinated lebih lama mencapai homozigot karena sifat tanaman jagung yang menyerbuk silang sehingga kemungkinan untuk silang diri (inbriding) sangat kecil $(<1 \%)$. Sehingga tanaman dengan perlakuan open pollinated ( $\mathrm{P} 1$ ) tidak banyak mengalami perubahan morfologi karena tanaman menyerbuk secara bebas dan kemungkinan silang diri penyebab depresi inbriding prosentasenya sangat kecil.

Perlakuan selfing (P2) mengalami sedikit penurunan pada karakter kadar gula biji, yaitu sebesar $0,2^{\circ}$ brix. Diduga karakter kadar gula pada tanaman perlakuan selfing (P2) dipengaruhi faktor genotipe sehingga kadar kemanisan tidak banyak mengalami penurunan meskipun dilakukan selfing selama beberapa generasi . Heritabilitas adalah perbandingan antara besaran ragam genotipe dengan besaran total ragam fenotipe dari suatu karakter. Hubungan ini menggambarkan seberapa jauh fenotipe yang tampak merupakan refleksi dari genotipe. Heritabilitas menetukan keberhasilan seleksi karena heretabilitas dapat memberikan petunjuk suatu sifat lebih dipengaruhi oleh faktor genetik atau faktor lingkungan (Suprapto dan Kairudin, 2007). Nilai heretabilitas yang tinggi menunjukkan bahwa faktor genetik lebih berperan dalam mengendalikan suatu sifat dibandingkan dengan faktor lingkungan (Knight dalam Suprapto dan Kairudin, 2007; Syukur $d k k$., 2012; Syukur $d k k ., 2011)$. Tanaman dengan heritabilitas tinggi tidak akan banyak mengalami perubahan karakter meskipun ditanam pada lingkungan dan musim yang berbeda karena sifat/karakter tersebut dikendalikan oleh gen indukannya. Sari $d k k$. (2003) melakukan penelitian tentang uji daya hasil 12 hibrida dan dilaporkan bahwa kadar gula biji memiliki nilai pendugaan heritabilitas arti luas tertinggi sehingga kadar gula dipengaruhi oleh genotip. Hal yang sama juga dilaporkan oleh Eltahir dan Saleh (2003) dan Eltahir et al. (2003). Dahlan dan Slamet (1992) menyatakan bahwa heritabilitas menentukan kemajuan seleksi, makin besar nilai heritabilitas makin besar kemajuan seleksi yang diraihnya dan makin cepat varietas unggul dilepas.

Syukur dkk. (2012) menyatakan bahwa tangkar dalam (inbreeding) adalah perkawinan antara individu yang mempunyai hubungan kekerabatan atau dapat dikatakan perkawinan antara saudara/kerabat terdekat. Tangkar dalam (inbreeding) dapat mengakibatkan penurunan karakter-karakter tanaman. Penurunan karakter ini secara genetik dapat dijelaskan bahwa dengan tangkar dalam, susunan genetik mengarah ke homozigot. Dengan adanya perubahan dari heterozigot ke homozigot ternyata memperlemah karakter-karakter tanaman. Gen-gen resesif yang tertutupi oleh gen dominan pada tanaman heterozigot akan bersegregasi dan meningkatkan homozigositas.

Selfing adalah bentuk tangkar dalam yang paling kuat (Saleh et al., 1993). Genotipe yang heterozigot akan berkurang separuhnya (50\%) di tiap generasi atau setelah beberapa generasi penyerbukan sendiri persentase lokus heterozigot akan semakin kecil (Syukur $d k k$., 2012). Tanaman perlakuan selfing (P2) merupakan hasil penyerbukan sendiri (selfing) selama 5 generasi. Apabila genotipe heterozigot pada generasi pertama $\left(\mathrm{F}_{1} / \mathrm{S}_{0}\right)$ sebesar $100 \%$ dan berkurang $50 \%$ pada tiap generasi selfing, pada generasi 5 penyerbukan sendiri persentase genotipe heterozigot menjadi 3,13\%. Sehingga tanaman perlakuan selfing (P2) diasumsikan telah homozigot dengan prosentase genotipe homozigot sebesar 96,87\%. Bila pasangan gen heterozigot lebih dari satu maka dengan sendirinya turunnya persentase heterozigot (meningkatnya persentase homozigot) tidak secepat bila hanya ada satu pasang gen. Hal ini berarti untuk melakukan fiksasi beberapa gen agar mendapatkan galur murni sesuai keinginan membutuhkan lebih banyak generasi selfing. Persentase sebaran homozigot dan heterozigot pada beberapa generasi inbreeding dapat dilihat pada Gambar 4.3 di bawah ini.

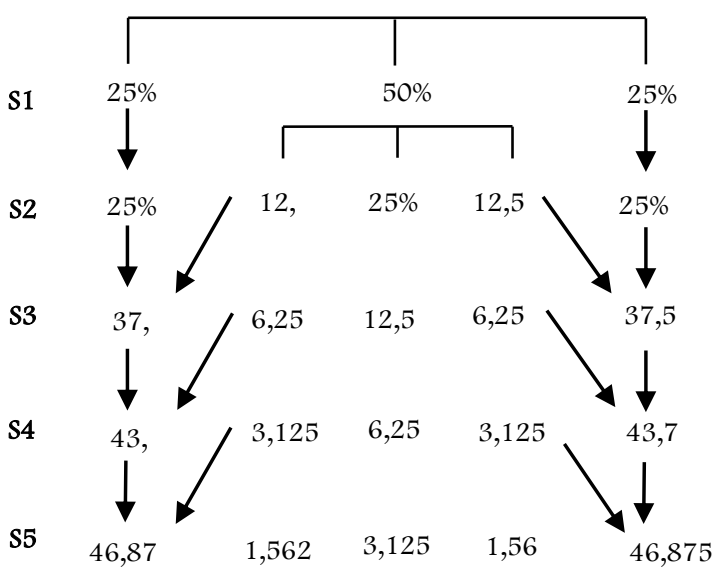


Gambar 4.3 Sebaran Homozigot dan Heterozigot Bila Satu Tanaman yang Heterozigot Pada Satu Lokus (Aa) Diserbuki Sendiri Sampai Lima Generasi (Syukur dkk., 2012).

Kesimpulan

Dari hasil pembahasan pada bab sebelumnya dapat disimpulkan:

1. Perlakuan open pollinated (P1) berbeda nyata dengan perlakuan selfing (P2) terhadap karakter tinggi tanaman, diameter batang, panjang daun, lebar daun, umur berbunga jantan, umur berbunga betina, umur panen, berat tongkol per tanaman, panjang tongkol, dan diameter tongkol dan kadar kemanisan biji tanaman jagung manis (Zea mays var. Saccharata Sturt.). Perlakuan open pollinated ( $\mathrm{P} 1)$ tidak berbeda nyata dengan perlakuan selfing (P2) terhadap karakter jumlah baris biji per tongkol tanaman jagung manis (Zea mays var. Saccharata Sturt.).

2. Besaran penurunan vigor pada perlakuan selfing (P2) lebih besar dibandingkan dengan perlakuan open pollinated (P1) pada seluruh karakter tanaman yang diamati. Penurunan vigor ditandai dengan besarnya nilai dan persentase Inbreeding Depresion (ID\%).

\section{Saran}

Perlu diadakan penelitian lebih lanjut mengenai inbreeding depression baik pada galur hasil self pollinated maupun open pollinated dengan galur yang lebih banyak.

\section{DAFTAR PUSTAKA}

Arnhold, E., , J.M.S. Viana, F. Mora, G.V Miranda, and R.G. Silva. 2010. Inbreeding Depression and Genetic Components for Popping Expansion and Other Traits in Brazilian Populations of Popcorn. Ciencia e Investigacion Agraria. 37 (3): 125-132.

Direktorat Jenderal Hortikultura Kementerian Pertanian. 2012. Volume Impor \& Ekspor Sayuran Th 2012. http://horti.pertanian.go.id/ [23 Mei 2014]

Cepy dan W. Wangiyana. 2011. Pertumbuhan dan Hasil Tanaman Padi (Oryza sativa L.) di Media Vertisol dan Entisol pada Berbagai Teknik Pengaturan Air dan Jenis Pupuk. Dalam Jurnal Crop Agro. Vol. 4(2): 49-56.
Dahlan, M. dan S. Slamet. 1992. Pemuliaan Tanaman Jagung. Prosiding Simposium Pemuliaan Tanaman I. Komda Jawa Timur. Hal. 17-38.

Eltahir, S. A. dan G. B. Saleh. 2003. Response of Two Cycles of Phenotypic Mass Selection and Heretability on Two Tropical Sweet Corn (Zea mays L. saccharata) Populations. Asian Journal of Plant $\begin{array}{llll}\text { Sciences. } & \text { Vol } & \text { 2(1): } & 65-70 .\end{array}$ http://198.170.104.138/ajps/2003/6570.pdf [29 Juni 2014]

Eltahir, S. A., G. B. Saleh, Z. B. Wahab dan A. A. Rahim. 2003. Performance, Heritability and Correlation Studies on Varieties and Population Cross of Sweet Corn. Asian Journal of Plant Sciences. Vol 2(10): 756760.

http://www.docsdrive.com/pdfs/ansinet/ajp s/2003/756-760.pdf [29 Juni 2014]

Harjadi, S. S. 1991. Pengantar Agronomi. Jakarta: Gramedia. 197 hal

Jafri. 2006. Tanggap Pertumbuhan Beberapa Varietas Jagung Terhadap Sistem Tanam Lurus dan Zigzag di Lahan Gambut Kalimantan Barat. Dalam Prosiding Seminar Nasional Serealia 2. !. hlm. 2330

Lumbanraja, P. 2013. Pengaruh Pola Pengolahan Tanah dan Pupuk Kandang Terhadap Beberapa Sifat Fisik Tanah Ultisol dan Pertumbuhan Vegetatif Tanaman Kacang Tanah (Arachis hypogea L.). Dalam Prosiding Seminar Nasional BKS-PTN Wilayah Barat Indonesia Pontianak. Kalimantan Barat. 19-20 Maret 2013. ISBN: 978-602-17664-1-5. Hal. 599-607.

Made, U. 2010. Respons Berbagai Populasi Tanaman Jagung Manis (Zea mays saccharata Sturt.) Terhadap Pemberian Pupuk Urea. Dalam Jurnal Agroland. Vol. 17 (2): 138-143.

Saleh, G. B., M. Y. Rafii, and T. C. Yap. 1993. Inbreeding Depression and Heterosis In Sweet Corn Varieties Manis Madu and Bakti-I. Pertanika Journal. Tropical 
Dwi Rahmawati, Tommy Yudistira,dan Saiful Mukhlis, Uji Inbreeding Depression Terhadap Karakter fenotipe Tanaman Jagung Manis (Zea mays var.Saccharata Sturt) Hasil Selfing Dan Pollinated

Agricultural Science. ISSN: 0126-6128. 16

(3): 209-214.

Sari, H. P., Suwarto dan M. Syukur. 2013. Daya Hasil 12 Hibrida Harapan Jagung Manis (Zea mays L. var. saccharata) di Kabupaten Maros, Sulawesi Selatan. Dalam Buletin Agrohorti. Vol 1(1): 14-22. http://journal.ipb.ac.id/index.php/bulagron larticle/download/6280/4835 $[01$ Juni 2014]

Siradjuddin, I. 2000. Uji Daya Hasil dan Pendugaan Nilai Heterosis pada Jagung Hibrida (Zea mays L.). Skripsi. Bogor: Fakultas Pertanian Institut Pertanian Bogor.

Suprapto dan N. M. Kairudin. 2007. Variasi Genetik, Heretabilitas, Tindak Gen dan Kemajuan Genetik Kedelai (Glycine max Merrill) Pada Ultisol. Dalam Jurnal IlmuIlmu Pertanian Indonesia. Vol. 9(2): 183190.

Suwarno, W.B. 2008. Perakitan Varietas Hibrida. http://willy.situshijau.co.id/downloads/jag ung-hibrida.pdf [15 Juni 2013].

Syukur, M., S. Sujiprihati, R. Yunianti dan D. A. Kusumah. 2011. Pendugaan Ragam Genetik dan Heretabilitas Karakter Komponen Hasil Beberapa Genotipe Cabai. Dalam Jurnal Agrivigor. Vol. 10(2): 148-156.

Syukur, M. dan A. Rifianto. 2013. Jagung Manis. Jakarta: Penebar Swadaya.

Syukur, M., S. Sujiprihati dan R. Yunianti. 2012. Teknik Pemuliaan Tanaman. Jakarta: Penebar Swadaya.

Takdir, A. M., S. Sunarti, M. J. Mejaya. Tanpa Tahun. Pembentukan Varietas Jagung Hibrida. http://pustaka.litbang.deptan.go.id/bppi/le ngkap /bpp10237.pdf [15 Juni 2013]. 